Jurnal Penelitian Karet, 2012, 30 (2) : 75 - 85

Indonesian J. Nat. Rubb. Res. 2012, 30 (2) : 75 - 85

\title{
OPTIMASI PRODUKSI KLON IRR SERI 200 DENGAN MENGGUNAKAN BEBERAPA SISTEM SADAP DI PENGUJIAN PLOT PROMOSI
}

\author{
Optimizing Yield IRR 200 Series using Some Tapping Systems in Plot Promotion Trial \\ Sekar WOELAN, JUNAIDI dan Syarifah Aini PASARIBU \\ Balai Penelitian Sungei Putih, Pusat Penelitian Karet \\ P.O. Box 1415 Medan 20001
}

Diterima tgl 21 April 2012 / Disetujui tgl 12 Agustus 2012

\begin{abstract}
A research was conducted to find out yield potency of IRR 200 series clones using some tapping systems. Beside optimizing yield, the results of this research could also be used for clone classification. The research was conducted in Promising Plot Trial at Sungei Putih Research Center, Deli Serdang, North Sumatra, from 2004 to 2011. The research location was at an elevation of around $54 \mathrm{~m}$ with ultisol soil type. Material used in this research was $1 \%$ best genotypes of IRR 200 series (PP/03/96) planted in 1995. There were 21 clones of IRR 200 series were tested. The control clones were BPM 24, PB 217 and $P B$ 260. The tapping systems used were $S / 2$ d2 and $S / 2$ d3.ET2.5\% Ga1 18/y(2w) (Apr-Dec) from 2004 to 2008, then continued with double cut $S / 2 d 3+S / 4 U$ d3.ET2.5\% Ba1(1.5) 18/y(2w) (Apr-Dec) from 2009 to 2011. The results of observation indicated that nine clones of IRR 200 series (IRR 200, IRR 202, IRR 207, IRR 209, IRR 210 , IRR 215, IRR 218, IRR 209) had more vigorous growth compared with control clones viz. average girth : $73.6 \mathrm{~cm}$ and girth increment $2.14 \mathrm{~cm} / \mathrm{yr}$. Consequently, these clones could be tapping in about 3.5 years a number of eight clones showed higher yield potency at $S / 2$ d2 and S/3 d3.ET2.5\% Ga1 18/y(2w) (Apr - Dec), viz. IRR 202, IRR 205, IRR 207, IRR 208, IRR 213, IRR 214 and IRR 220. These eight clones showed potency as superior new clones. Classification of IRR 200 series based on clone tipology showed that IRR 202, IRR 208, IRR 208, IRR 210, and IRR 220 as quick stater due to their high metabolism and less response to stimulant, while IRR 213 and IRR 214 as slow stater due to their low metabolism and response to stimulant. Further research until one cycle was suggested to find out comprehensive data and complete clone characters with analysis oflatex diagnosis.
\end{abstract}

Keywords: Hevea brasiliensis, IRR 200 series clones, yield potency, quick starter, slow starter.
Abstrak

Suatu pengujian dilakukan untuk mengetahui potensi produksi masingmasing klon IRR seri 200 melalui penerapan beberapa sistem sadap. Di samping untuk mengoptimalkan produksi, hasil pengujian ini juga berguna sebagai salah satu pertimbangan dalam pengelompokan klon nantinya. Pengujian dilaksanakan pada areal pengujian plot promosi di Kebun Percobaan Balai Penelitian Sungei Putih, Deli Serdang - Sumatera Utara mulai tahun 2004 sampai tahun 2011. Lokasi pengujian berada pada ketinggian sekitar $54 \mathrm{~m}$ di atas permukaan laut (dpl) dengan jenis tanah Ultisol. Material yang digunakan dalam pengujian ini adalah $1 \%$ genotipe terbaik dari klon IRR seri 200 (PP/03/96) tahun tanam 1995. Sejumlah 21 klon IRR seri 200 diuji dan 3 klon pembanding masingmasing BPM 24, PB 217 dan PB 260. Sistem sadap yang diuji cobakan adalah $\mathrm{S} / 2 \mathrm{~d} 2$ dan S/2 d3.ET2.5\% Ga1 18/y(2w) (Apr Des) pada tahun 2004 - 2008 dan dilanjutkan dengan sistem sadap ganda $\mathrm{S} / 2 \mathrm{~d} 3+\mathrm{S} / 4 \mathrm{U}$ d3. ET2.5\% Ba1(1.5) 18/y(2w) (Apr - Des) pada tahun 20092011. Hasil pengamatan menunjukkan bahwa terdapat sembilan klon IRR seri 200 (IRR 200, IRR 202, IRR 207, IRR 209, IRR 210, IRR 215, IRR 218, IRR 219) yang memiliki pertumbuhan lilit batang lebih jagur dari ketiga klon pembanding sehingga potensial dapat disadap pada umur sekitar 3,5 tahun dengan rata-rata lilit batang sebesar 73,6 cm dan rata-rata laju pertambahan lilit batang sebesar 2,14 $\mathrm{cm} /$ tahun. Hasil pengamatan terhadap produktivitas tanaman menunjukkan terdapat delapan klon yang memiliki potensi produksi tinggi pada sistem sadap $\mathrm{S} / 2 \mathrm{~d} 2$ dan S/3 d3.ET2.5\%Ga1 18/y(2w) (Apr-Des) yaitu IRR 202 , IRR 205, IRR 207, IRR 208, IRR 213, IRR 214 dan IRR 220. Kedelapan klon tersebut berpotensi sebagai 
klon unggul baru. Pengelompokan klon IRR seri 200 berdasarkan tipologi klon menunjukkan bahwa klon IRR 202, IRR 208, IRR 210, dan IRR 220 cenderung sebagai klon quick starter karena memiliki metabolisme tinggi dan kurang responsif terhadap pemberian stimulan, sedangkan IRR 213 dan IRR 214 cenderung sebagai klon slow starter karena memiliki metabolisme rendah dan lebih responsif terhadap pemberian stimulan. Disarankan agar dilakukan penelitian lanjutan sampai satu siklus tanaman (20 tahun sadap) dan dilengkapi dengan data analisis diagnosis lateks.

Kata kunci: Hevea brasiliensis, IRR seri 200, potensi produksi, quick starter, slow starter

\section{PENDAHULUAN}

Klon unggul adalah komponen teknologi terpenting bagi keberhasilan perkebunan karet. Secara ekonomi, klon unggul berperan terhadap peningkatan pendapatan pekebun melalui peningkatan produksi dan penurunan biaya pemeliharaan sehingga harga pokok per kilogram produk yang dihasilkan menjadi lebih rendah. Potensi produksi klon unggul karet pada saat ini rata-rata sekitar 2000 - 2500 $\mathrm{kg} / \mathrm{ha} /$ tahun dan secara genetik masih dapat dilipatgandakan melalui perakitan genotipe yang memiliki kapasitas fotosintesis lebih tinggi dan lebih efisien dalam konversi asimilat menjadi lateks (Templeton, 1969a; 1969b; Simmonds, 1989).

Sebelum klon unggul baru direkomendasikan untuk ditanam secara luas, klon tersebut terlebih dahulu harus diuji melalui beberapa tahapan seleksi pemuliaan tanaman karet. Proses seleksi dalam pemuliaan karet dilakukan secara bertahap yang dimulai dengan memilih genotipe terbaik dari sumber-sumber yang ada atau menyeleksi semaian hasil persilangan di pembibitan atau di Seedling Evalution Trial (SET) kemudian klon-klon tersebut diperbanyak secara vegetatif dan kemudian dievaluasi pada beberapa tahapan berikutnya, yaitu pengujian pendahuluan, pengujian lanjutan, dan pengujian adaptasi (Ginting, 1984; Aidi-Daslin, 2004). Waktu yang dibutuhkan dalam satu siklus pemuliaan tanaman karet mencapai 25-30 tahun. Salah satu upaya mempersingkat siklus tersebut adalah melalui pengujian plot promosi (Tan, 1987). Pengujian plot promosi dilakukan dengan cara mengambil $1 \%$ genotipe terbaik pada hasil persilangan, melalui pengujian ini satu siklus pemuliaan tanaman dapat dipersingkat menjadi $15-20$ tahun.

Saat ini telah tersedia dua populasi hasil persilangan buatan yang dilakukan antara tahun 1985 - 1991 (Woelan, 1998; Aidi Daslin, 2004) yang merupakan materi seleksi untuk klon IRR seri 100, 200 dan 300. Dari kedua populasi tersebut telah terpilih 627 tanaman F1 (ortet) berdasarkan pertumbuhan dan hasil lateks (Azwar et al., 1999). Ortet terpilih tersebut diperbanyak secara vegetatif dan dijadikan bahan pengujian pada tahap pengujian pendahuluan $(10 \%$ terbaik) dan plot promosi $(1 \%$ terbaik).

Pada tahapan pengujian plot promosi, seleksi dititikberatkan pada aspek pertumbuhan dan potensi produksi tanaman yang dilaksanakan dalam skala yang relatif kecil. Sebelum direkomendasikan untuk penanaman skala komersial, klon-klon harapan yang diperoleh nantinya perlu diuji dan dievaluasi dalam skala yang lebih luas dalam pengujian lanjutan dan adaptasi untuk mengetahui respons klon terhadap variasi sistem budidaya dan lingkungan tumbuh.

Pada tanaman karet, produksi yang diperoleh sangat dipengaruhi oleh sistem sadap yang diterapkan. Filosofi dalam pemanenan lateks pada tanaman karet adalah mengambil sebanyak mungkin dan sesering mungkin lateks yang ada dalam pembuluh lateks, namun tidak menyebabkan dampak keletihan fisiologis pada tanaman sehingga diperoleh produktivitas yang optimal (Sumarmadji, 2000). Sistem sadap memiliki peranan penting untuk mengoptimalkan potensi produksinya.

Setiap klon memiliki karakter fisiologis yang spesifik sehingga respons tanaman terhadap sistem sadap yang diaplikasikan juga beragam. Klon-klon dengan metabolisme tinggi cenderung responsif terhadap interval penyadapan tinggi namun kurang responsif terhadap pemberian stimulan. Klon-klon yang memiliki metabolisme 
sedang dan rendah cenderung responsif terhadap pemberian stimulan namun memerlukan interval penyadapan yang lebih panjang. Berdasarkan karakter fisiologis, respons tanaman terhadap sistem sadap serta potensi produksinya umumnya dibedakan menjadi klon slow starter dan quick starter. Azwar dan Suhendry (1998) menyatakan bahwa quick starter dicirikan dengan puncak produksi yang diperoleh pada periode awal penyadapan, sedangkan slow starter cenderung puncak produksinya diperoleh pada pertengahan siklus penyadapannya.

Dengan pertimbangan bahwa respons tanaman terhadap sistem sadap yang digunakan dapat berbeda pada setiap klonnya, maka dirasa perlu untuk melakukan kajian pada klon IRR seri 200 di plot promosi untuk melihat potensi produksi masing-masing klon pada beberapa sistem sadap. Selain untuk mengoptimalkan produksi, hasil pengujian ini juga berguna sebagai salah satu pertimbangan pengelompokan klon IRR seri 200 nantinya.

\section{BAHAN DAN METODE}

Pengujian dilaksanakan di Kebun Percobaan Balai Penelitian Sungei Putih, Deli Serdang - Sumatera Utara mulai tahun 2002 sampai tahun 2011. Lokasi pengujian berada pada ketinggian Sekitar $35 \mathrm{~m}$ di atas permukaan laut (dpl) dengan jenis tanah Ultisol. Material yang digunakan adalah $1 \%$ genotipe terbaik dari klon IRR seri 200 (PP/03/96) tahun tanam 1996. Pengujian dibangun menurut rancangan Simple Latice Design atau Augmented RCB dengan jarak tanam $5 \mathrm{mx} 4 \mathrm{~m}$, masing-masing plot terdiri atas 30 - 72 tanaman. Perlakuan yang diujicobakan meliputi perlakuan klon dan sistem sadap. Pada perlakuan klon digunakan 21 klon IRR seri 200 dan 3 klon pembanding yakni BPM 24, PB 217, dan PB 260 (Tabel 1).

Sistem sadap yang diterapkan terdiri atas dua perlakuan yakni perlakuan pertama yang menggunakan sistem sadap setengah lingkaran tanpa stimulan dengan interval penyadapan dua hari sekali (S/2 d2) pada tahun 2004 - 2008 (tahun sadap ke-4 sampai ke-8), sedangkan perlakuan ke-2 pada periode tersebut menggunakan sistem sadap setengah lingkaran dengan interval penyadapan tiga hari sekali dan aplikasi stimulan etepon 2,5\% (S/2 d3.ET2.5\%Ga1 $18 / \mathrm{y}(2 \mathrm{w})$ (Apr-Des)). Selanjutnya pada tahun 2009 - 2011 (tahun sadap ke-9 sampai ke-11) seluruh perlakuan menggunakan sistem sadap ganda (double cut) dengan irisan setengah lingkaran pada kulit pulihan pertama (BI-1) dan seperempat lingkaran ke arah atas pada panel HO-1 (S/2 d3+S/4U d3.ET2.5\% Ba1(1.5) 18/y(2w) (Apr-Des)) (Tabel 2).

Parameter-parameter yang diamati pada pengujian ini adalah karakter pertumbuhan (lilit batang dan laju pertumbuhan) serta potensi produksi (produksi per pohon per sadap $(\mathrm{g} / \mathrm{p} / \mathrm{s})$ dan produksi per hektar per tahun (kg/ha/thn). Parameter pertumbuhan masing-masing klon diamati setiap enam bulan, sedangkan data produksi dicatat setiap kali dilaksanakan penyadapan pada areal pengujian.

\section{HASIL DAN PEMBAHASAN}

\section{Karakter Pertumbuhan}

Pertumbuhan tanaman adalah salah satu faktor utama yang menjadi pertimbangan dalam seleksi klon unggul baru. Klon IRR seri 200 merupakan klon hasil persilangan tahun 1990 yang sebagian besar merupakan turunan dari induk betina klon PB 260, oleh karena itu pertumbuhannya sedang dan penampilannya seperti klon PB 260 (self prunning dan terdapat benjolan bekas cabang). Perkembangan lilit batang klon IRR seri 200 pada pengujian plot promosi di Kebun Percobaan Sungei Putih diamati secara kontinu sehingga memiliki peluang sebagai salah satu populasi calon klon unggul baru. Perkembangan lilit batang klon IRR seri 200 pada tahun ke-9 sampai ke-16 disajikan pada Tabel 2.

Secara umum pertumbuhan klonklon IRR seri 200 lebih jagur dibandingkan dengan ketiga klon pembanding (BPM 24, PB 217 dan PB 260). Rata-rata lilit batang klon IRR seri 200 sampai dengan tahun ke16 setelah tanam adalah $73,6 \mathrm{~cm}$ sedangkan klon pembanding sebesar 65,83 $\mathrm{cm}$. Lilit batang terendah pada klon IRR 217 $(62,2 \mathrm{~cm})$ sedangkan tertinggi pada klon IRR 
Tabel 1. Klon pada pengujian plot promosi

Table 1. Treatment in promotion plot trial

\begin{tabular}{|c|c|c|}
\hline No. & $\begin{array}{l}\text { Klon } \\
\text { Clones }\end{array}$ & $\begin{array}{l}\text { Tetua } \\
\text { Parents }\end{array}$ \\
\hline \multicolumn{3}{|c|}{$\begin{array}{l}\text { Klon IRR seri } 200 \\
\text { IRR } 200 \text { series }\end{array}$} \\
\hline 1. & IRR 200 & PB $260 \times$ FX 25 \\
\hline 2. & IRR 201 & PB 260 x RRIC 102 \\
\hline 3. & IRR 202 & RRIC 110 x AVROS 427 \\
\hline 4. & IRR 203 & BPM 109 x FX 2784 \\
\hline 5. & IRR 204 & PB 260 x BPM 101 \\
\hline 6. & IRR 205 & PB 260 x BPM 101 \\
\hline 7. & IRR 206 & PB $260 \times$ BPM 101 \\
\hline 8. & IRR 207 & BPM 24 x IAN 873 \\
\hline 9. & IRR 208 & BPM 24 x IAN 873 \\
\hline 10. & IRR 209 & PB 260 x F 4542 \\
\hline 11. & IRR 210 & PB $260 \times$ FX 2784 \\
\hline 12. & IRR 211 & PB $260 \times$ IAN 873 \\
\hline 13. & IRR 212 & IAN 873 x PB 26 \\
\hline 14. & IRR 213 & IAN $873 \times$ PB 260 \\
\hline 15. & IRR 214 & IAN $873 \times$ PB 260 \\
\hline 16. & IRR 215 & PB $260 \times$ IAN 873 \\
\hline 17. & IRR 216 & PB 260 x F 4542 \\
\hline 18. & IRR 217 & PB $260 \times$ F 4542 \\
\hline 19. & IRR 218 & BPM 101 x RRIC 102 \\
\hline 20. & IRR 219 & PB $260 \times$ IAN 873 \\
\hline 21. & IRR 220 & PB 260 x IAN 873 \\
\hline \multicolumn{3}{|c|}{$\begin{array}{l}\text { Klon pembanding } \\
\text { Control clones }\end{array}$} \\
\hline 1 & BPM 24 & GT1 x AVROS 1734 \\
\hline 2 & PB 217 & PB 5/51 x PB 6/9 \\
\hline 3 & PB 260 & PB 5/51 x PB 49 \\
\hline
\end{tabular}

Tabel 2. Perlakuan sistem sadap pada pengujian plot promosi

Table 2. Tapping system treatment in promotion plot trial

\begin{tabular}{ccc}
\hline $\begin{array}{c}\text { Tahun sadap } \\
\text { Tapping year } \\
\text { (th } / y \text { r) }\end{array}$ & $\begin{array}{c}\text { Perlakuan 1 } \\
\text { Treatment 1 }\end{array}$ & $\begin{array}{c}\text { Perlakuan 2 } \\
\text { Treatment 2 }\end{array}$ \\
\hline $\begin{array}{c}\text { Ke }-4-\mathrm{ke}-8 \\
4^{\text {th }}-8^{\text {th }}\end{array}$ & $\mathrm{S} / 2 \mathrm{~d} 2$ & $\mathrm{~S} / 2 \mathrm{~d} 3 . \mathrm{ET} 2.5 \% \mathrm{Ga} 1$ 18/y(2w) (Apr-Dec) \\
$(2004-2008)$ & & \\
$\mathrm{Ke}-9-\mathrm{ke}-11$ & $\mathrm{~S} / 2 \mathrm{~d} 3+\mathrm{S} / 4 \mathrm{U}$ d3.ET2.5\%Ba1(1.5) $18 / \mathrm{y}(2 \mathrm{w})(\mathrm{Apr}-\mathrm{Dec})$ \\
$9^{\text {th }}-11^{\text {th }}$ & & \\
$(2009-2011)$ & & \\
\hline
\end{tabular}


Tabel 3. Lilit batang klon IRR seri 200 di plot promosi pada tahun ke-4 sampai ke-11 setelah tanam

Table 3. Girth of IRR 200 series in $4^{\text {th }}$ to $11^{\text {th }}$ year after planting

\begin{tabular}{|c|c|c|c|c|c|c|c|c|c|c|}
\hline \multirow{3}{*}{ No. } & \multirow{3}{*}{$\begin{array}{l}\text { Klon } \\
\text { Clones }\end{array}$} & \multicolumn{8}{|c|}{ Umur tanaman (tahun) / Plant age (year) } & \multirow{3}{*}{$\begin{array}{c}\text { Rata-rata pertam- } \\
\text { bahan lilit batang } \\
(\mathrm{cm} / \mathrm{thn}) \\
\text { Average girth } \\
\text { increment }(\mathrm{cm} / \mathrm{yr})\end{array}$} \\
\hline & & 4 & 5 & 6 & 7 & 8 & 9 & 10 & 11 & \\
\hline & & \multicolumn{8}{|c|}{$\begin{array}{c}\text {...Lilit batang }(\mathrm{cm}) \\
\text { Girth }(\mathrm{cm})\end{array}$} & \\
\hline \multicolumn{11}{|c|}{ Klon IRR seri 200 ( IRR 200 series) } \\
\hline 1 & IRR 200 & 62,4 & 64,9 & 66,1 & 66,2 & $\mathbf{7 1 , 5}$ & 76,4 & 77,3 & 79,5 & 2,44 \\
\hline 2 & IRR 201 & 53,7 & 54,5 & 55,3 & 55,9 & 57,5 & 61,0 & 63,1 & 64,4 & 1,53 \\
\hline 3 & IRR 202 & 66,5 & 70,2 & $\mathbf{7 4 , 2}$ & $\mathbf{7 5 , 7}$ & 82,9 & 86,3 & 90,8 & 91,7 & 3,60 \\
\hline 4 & IRR 203 & 56,0 & 57,4 & 58,7 & 59,7 & 62,6 & 63,0 & 65,7 & 65,7 & 1,39 \\
\hline 5 & IRR 204 & 55,2 & 56,3 & 57,1 & 58,7 & 61,3 & 64,1 & 67,5 & 68,3 & 1,87 \\
\hline 6 & IRR 205 & 57,1 & 58,4 & 59,2 & 59,7 & 61,5 & 70,1 & 71,2 & 71,9 & 2,11 \\
\hline 7 & IRR 206 & 54,4 & 55,7 & 56,5 & 58,7 & 59,6 & 60,6 & 67,1 & 68,6 & 2,03 \\
\hline 8 & IRR 207 & 63,2 & 64,7 & 65,6 & 65,9 & 69,8 & 73,5 & 78,0 & 78,6 & 2,20 \\
\hline 9 & IRR 208 & 56,2 & 57,4 & 59,1 & 59,4 & 61,2 & 65,6 & 66,0 & 66,3 & 1,44 \\
\hline 10 & IRR 209 & 53,3 & 54,7 & 55,3 & 55,9 & 60,3 & 61,8 & 66,2 & 69,6 & 2,33 \\
\hline 11 & IRR 210 & 70,2 & 71,4 & 74,8 & 75,7 & 77,1 & 78,1 & 85,8 & 89,4 & 2,74 \\
\hline 12 & IRR 211 & 58,6 & 60,2 & 61,3 & 62,1 & 63,1 & 71,3 & 72,9 & 73,3 & 2,10 \\
\hline 13 & IRR 212 & 58,5 & 59,0 & 61,5 & 61,9 & 64,0 & 67,9 & 73,1 & 74,6 & 2,30 \\
\hline 14 & IRR 213 & 50,5 & 51,4 & 53,1 & 54,1 & 61,7 & 62,9 & 64,7 & 65,2 & 2,10 \\
\hline 15 & IRR 214 & 55,5 & 56,1 & 57,3 & 58,3 & 60,7 & 64,2 & 68,8 & 69,7 & 2,03 \\
\hline 16 & IRR 215 & 59,6 & 61,1 & 63,7 & 64,4 & 67,9 & 72,0 & 78,8 & 81,5 & 3,13 \\
\hline 17 & IRR 216 & 52,9 & 54,3 & 55,1 & 55,6 & 57,8 & 62,9 & 65,4 & 65,8 & 1,84 \\
\hline 18 & IRR 217 & 52,7 & 53,6 & 54,1 & 54,4 & 56,1 & 58,2 & 60,0 & 62,2 & 1,36 \\
\hline 19 & IRR 218 & 69,9 & 73 & 73,9 & $\mathbf{7 4 , 1}$ & $\mathbf{7 4 , 9}$ & 83,5 & 85,1 & 85,3 & 2,20 \\
\hline 20 & IRR 219 & 62,3 & 62,8 & 63,4 & 64,0 & 65,4 & 70,1 & $\mathbf{7 4 , 7}$ & $\mathbf{7 7 , 4}$ & 2,16 \\
\hline 21 & IRR 220 & 61,5 & 63,4 & 64,0 & 65,1 & 68,8 & 71,8 & 73,4 & 75,6 & 2,01 \\
\hline \multicolumn{11}{|c|}{ Klon pembanding ( Control clones) } \\
\hline 22 & BPM 24 & 49,1 & 50,2 & 51,2 & 52,1 & 55,2 & 56,1 & 56,2 & 59,3 & 1,46 \\
\hline 23 & PB 217 & 57,3 & 58,4 & 59,9 & 60,2 & 62,2 & 64,4 & 67,1 & 69,1 & 1,69 \\
\hline 24 & PB 260 & 54,0 & 54,8 & 56,6 & 56,9 & 58,2 & 60,4 & 63,3 & 69,1 & 2,16 \\
\hline
\end{tabular}

$202(91,7 \mathrm{~cm})$. Dari hasil pengamatan terhadap perkembangan lilit batang klonklon IRR seri 200 terdapat beberapa klon yang memiliki lilit batang lebih besar daripada rataan yaitu IRR $200(79,5 \mathrm{~cm})$, IRR $202(91,7 \mathrm{~cm})$, IRR $207(78,6 \mathrm{~cm})$, IRR 210 $(89,4 \mathrm{~cm})$, IRR $212(74,6 \mathrm{~cm})$, IRR $215(81,5$ cm), IRR $219(77,4 \mathrm{~cm})$ dan IRR $220(75,6$ $\mathrm{cm})$.

Laju pertumbuhan lilit batang klonklon IRR seri 200 di plot promosi cukup bervariasi $(\mathrm{CV}=25,34 \%)$ dengan rata-rata $2,14 \mathrm{~cm} / \mathrm{th}$. Laju pertumbuhan tersebut lebih tinggi dibanding klon-klon pembanding $(1,77 \mathrm{~cm} /$ th). Klon-klon IRR seri 200 yang memiliki laju pertumbuhan di atas rata-rata adalah IRR $200(2,44 \mathrm{~cm} / \mathrm{th})$, IRR $202(3,60 \mathrm{~cm} /$ th), IRR $207(2,20 \mathrm{~cm} / \mathrm{th})$, IRR 209 (2,33 cm/th), IRR $210(2,74 \mathrm{~cm} / \mathrm{th})$, IRR 215 (3,13 cm/th), IRR $218(2,20 \mathrm{~cm} / \mathrm{th})$, dan IRR 219 (2,16 cm/th) (Tabel 3). Pertumbuhan tanaman yang jagur dengan pertambahan lilit batang baik yang sangat diperlukan sehingga klon tersebut diharapkan mencapai kriteria matang sadap yang lebih singkat (sekitar 3,5 tahun). 
Tabel 4. Potensi produksi klon pada perlakuan 1

Table 4. Yield potency clone in treatment 1

\begin{tabular}{|c|c|c|c|c|c|c|c|c|c|c|c|}
\hline \multirow{3}{*}{ No. } & \multirow{3}{*}{$\begin{array}{l}\text { Klon } \\
\text { Clones }\end{array}$} & \multicolumn{8}{|c|}{$\begin{array}{l}\text { Tahun sadap ke-n } \\
n \text { tapping year }\end{array}$} & \multirow{3}{*}{$\begin{array}{r}\text { Rataan } \\
(\mathrm{g} / \mathrm{p} / \mathrm{s}) \\
\text { Average } \\
(g / t / t)\end{array}$} & \multirow{3}{*}{$\begin{array}{l}\text { Rataan } \\
\text { (kg/ha/th) } \\
\text { Average } \\
(\mathrm{kg} / \mathrm{ha} / \mathrm{yr})\end{array}$} \\
\hline & & \multirow[t]{2}{*}{4} & \multirow[t]{2}{*}{5} & \multirow[t]{2}{*}{6} & \multirow{2}{*}{$\begin{array}{c}7 \\
\mathrm{~g} / \mathrm{p} / \mathrm{s}\end{array}$} & 8 & \multirow{2}{*}{9} & 10 & \multirow[t]{2}{*}{11} & & \\
\hline & & & & & & \multicolumn{2}{|c|}{$(g / t / t) \ldots \ldots \ldots \ldots \ldots \ldots \ldots \ldots \ldots \ldots \ldots \ldots$} & & & & \\
\hline \multicolumn{12}{|c|}{$\begin{array}{l}\text { Klon IRR seri } 200 \\
\text { IRR } 200 \text { series }\end{array}$} \\
\hline 1 & IRR 200 & 26.3 & 33.0 & 42.1 & 48.8 & 58.8 & 30.2 & 19.8 & 23.3 & 35.3 & $1,553.2$ \\
\hline 2 & IRR 201 & 31.2 & 41.3 & 47.9 & 51.0 & 59.5 & 29.4 & 21.6 & 16.9 & 37.3 & $1,641.2$ \\
\hline 3 & IRR 202 & 32.0 & 40.7 & 69.5 & 86.9 & $\begin{array}{c}100 . \\
3\end{array}$ & 53.4 & 88.4 & 62.9 & 66.8 & $2,939.2$ \\
\hline 4 & IRR 203 & 28.3 & 31.5 & 39.1 & 50.4 & 61.3 & 49.5 & 27.5 & 27.6 & 39.4 & $1,733.6$ \\
\hline 5 & IRR 204 & 31.7 & 34.3 & 52.3 & 53.8 & 58.5 & 43.6 & 49.3 & 31.7 & 44.4 & $1,953.6$ \\
\hline 6 & IRR 205 & 31.4 & 29.4 & 44.6 & 58.7 & 55.5 & 75.1 & 45.8 & 32.2 & 46.6 & $2,050.4$ \\
\hline 7 & IRR 206 & 31.8 & 36.3 & 45.0 & 41.0 & 39.9 & 43.7 & 35.5 & 29.7 & 37.9 & $1,667.6$ \\
\hline 8 & IRR 207 & 34.7 & 47.0 & 44.5 & 53.9 & 59.7 & 83.1 & 68.8 & 34.5 & 53.3 & $2,345.2$ \\
\hline 9 & IRR 208 & 38.2 & 43.8 & 50.9 & 77.8 & 80.5 & 49.6 & 54.1 & 27.9 & 52.8 & $2,323.2$ \\
\hline 10 & IRR 209 & 28.8 & 26.6 & 36.3 & 39.9 & 41.1 & 36.1 & 26.6 & 26.0 & 32.7 & $1,438.8$ \\
\hline 11 & IRR 210 & 37.0 & 53.8 & 61.5 & 72.8 & 85.7 & 56.2 & 98.1 & 56.5 & 65.2 & $2,868.8$ \\
\hline 12 & IRR 211 & 36.8 & 43.3 & 54.8 & 50.3 & 70.0 & 35.3 & 26.6 & 25.0 & 42.8 & $1,883.2$ \\
\hline 13 & IRR 212 & 30.8 & 37.0 & 46.5 & 53.4 & 58.8 & 40.4 & 27.5 & 24.2 & 39.8 & $1,751.2$ \\
\hline 14 & IRR 213 & 32.3 & 37.9 & 47.4 & 46.7 & 44.4 & 107.3 & 63.2 & 38.9 & 52.3 & $2,301.2$ \\
\hline 15 & IRR 214 & 19.5 & 34.3 & 45.8 & 64.1 & 63.9 & 76.3 & 62.4 & 28.0 & 49.3 & $2,169.2$ \\
\hline 16 & IRR 215 & 31.0 & 39.5 & 48.3 & 45.4 & 58.4 & 36.1 & 36.5 & 20.3 & 39.4 & $1,733.6$ \\
\hline 17 & IRR 216 & 31.5 & 41.0 & 48.9 & 47.8 & 64.3 & 40.7 & 43.9 & 26.4 & 43.1 & $1,896.4$ \\
\hline 18 & IRR 217 & 31.8 & 36.8 & 49.8 & 50.7 & 47.4 & 45.5 & 29.2 & 21.4 & 39.1 & $1,720.4$ \\
\hline 19 & IRR 218 & 34.0 & 31.7 & 43.6 & 49.0 & 58.3 & 42.7 & 26.7 & 26.5 & 39.1 & $1,720.4$ \\
\hline 20 & IRR 219 & 32.1 & 42.3 & 47.7 & 42.8 & 53.1 & 29.7 & 43.6 & 25.6 & 39.6 & $1,742.4$ \\
\hline 21 & IRR 220 & 43.0 & 51.2 & 60.6 & 64.4 & 86.3 & 63.9 & 42.4 & 31.0 & 55.3 & $2,433.2$ \\
\hline \multicolumn{12}{|c|}{ Klon pembanding } \\
\hline 22 & BPM 24 & 37.4 & 33.3 & 52.1 & 56.1 & 55.4 & 33.0 & 33.6 & 37.3 & 42.3 & $1,861.2$ \\
\hline 23 & PB 217 & 34.2 & 41.8 & 53.3 & 48.7 & 89.1 & 51.5 & 44.3 & 33.2 & 49.5 & $2,178.0$ \\
\hline 24 & PB 260 & 36.9 & 42.2 & 68.3 & 57.5 & 67.4 & 47.2 & 33.8 & 25.8 & 47.4 & $2,085.6$ \\
\hline
\end{tabular}

\section{Potensi Produksi}

Klon-klon unggul baru diharapkan memiliki potensi produksi yang lebih tinggi dibandingkan dengan klon-klon yang sudah ada. Untuk menggoptimalkan potensi produksi tanaman diperlukan sistem sadap yang tepat sehingga produksi yang diperoleh tinggi dan berkelanjutan. Sumarmadji (2000) menyatakan bahwa eksploitasi tanaman karet dewasa ini diarahkan melalui sistem eksploitasi yang spesifik-diskriminatif antara lain terhadap jenis klon, variasi musim dan umur tanaman.

Potensi produksi dari klon IRR seri 200 dilihat dari kemampuannya menghasilkan lateks pada sistem sadap $\mathrm{S} / 2$ $\mathrm{d} 2$, sistem sadap ini dianggap sebagai acuan dasar pemanenan lateks yang memiliki intensitas penyadapan $100 \%$. Hasil pengamatan terhadap produksi pada perlakuan 1 yang menggunakan sistem sadap $\mathrm{S} / 2 \mathrm{~d} 2$ pada tahun sadap ke-4 - ke-8 dan penyadapan double cut $(\mathrm{S} / 2 \mathrm{~d} 3+\mathrm{S} / 4 \mathrm{U}$ d3.ET2.5\%Ba1(1.5) 18/y(2w) (Apr-Des) pada tahun ke-9 - ke 11 disajikan pada Tabel 4. Rata-rata potensi produksi klonklon IRR seri 200 pada perlakuan 1 mencapai 45,3 g/p/s. Rata-rata tersebut lebih rendah dibanding rata-rata klon pembanding yang mencapai $46,4 \mathrm{~g} / \mathrm{p} / \mathrm{s}$. Pada perlakuan 1 terdapat delapan klon IRR seri 200 yang memiliki potensi produksi 
(g/p/s) lebih tinggi bila dibandingkan dengan rata-rata potensi produksi klon kontrol antara lain IRR 202 (66,8), IRR 205 $(46,6)$, IRR $207(53,3)$, IRR $208(52,8)$, IRR $210(65,2)$, IRR $213(52,3)$, IRR $214(49,3)$ dan IRR 220 (55,3). Jika potensi produksi per hektar per tahun dihitung berdasarkan asumsi jumlah populasi 400 pohon/ha dan hari sadap efektif sebanyak 110 hari/tahun, maka produksi tertinggi diperoleh pada klon IRR 202 (2,93 ton/ha/tahun) sedangkan terendah pada klon IRR 209 (1,43 ton/ha/tahun).

Pada perlakuan 2 digunakan sistem sadap S/2 d3.ET2.5\% Ga1 18/y(2w) (AprDes) pada tahun sadap ke-4 - ke-8 dan double cut (S/2 d3+S/4U d3.ET2.5\% Ba1(1.5) 18/y(2w) (Apr-Des) pada tahun ke9 - ke 11. Rata-rata potensi produksi klonklon IRR seri 200 pada perlakuan 2 adalah sebesar 49,64 g/p/s. Rata-rata tersebut relatif sama dibanding rata-rata klon pembanding sebesar 49,56 g/p/s. Pada perlakuan 2 terdapat sembilan klon IRR seri 200 yang memliki potensi produksi (g/p/s) lebih tinggi bila dibandingkan dengan ratarata potensi produksi klon kontrol antara lain IRR $202(77,6)$, IRR $204(51,8)$, IRR 205 (50,8), IRR 207 (62,2), IRR 208 (53,3), IRR $210(67,6)$, IRR $213(60,7)$, IRR $214(61,2)$ dan IRR 220 (56,0) (Tabel 5). Produksi per hektar per tahun tertinggi diperoleh pada klon IRR $202(3,41$ ton/ha/tahun) sedangkan terendah pada klon IRR 218 (1,60 ton/ha/tahun).

Rata-rata produksi kumulatif klonklon IRR 200 pada perlakuan 2 mencapai 17,47 ton/ha. Produksi tertinggi pada klon IRR 202 dengan produksi kumulatif sebesar 27,30 ton/ha, sedangkan terendah pada klon IRR 218 dengan produksi kumulatif 12,81 ton/ha. Adapun rata-rata produksi kumulatif klon-klon pembanding adalah $17,44 \mathrm{~kg} /$ ha (Gambar 1).

Dari hasil pengamatan terhadap potensi produksi pada perlakuan 1 dan 2 , dari 21 klon IRR seri 200 yang diujicobakan, terdapat delapan klon yang memiliki potensi produksi lebih tinggi dibanding rata-rata klon pembanding yaitu IRR 202, IRR 205, IRR 207, IRR 208, IRR 210, IRR 213, IRR 214, dan IRR 220. Klon-klon tersebut sangat potensial sebagai klon unggul baru. Selanjutnya, berdasarkan karakteristik umum tipologi klonal, klon-klon dapat dikelompokkan menjadi klon quick starter dan slow starter. Siregar et al.(2008) menyatakan bahwa klon-klon quick starter

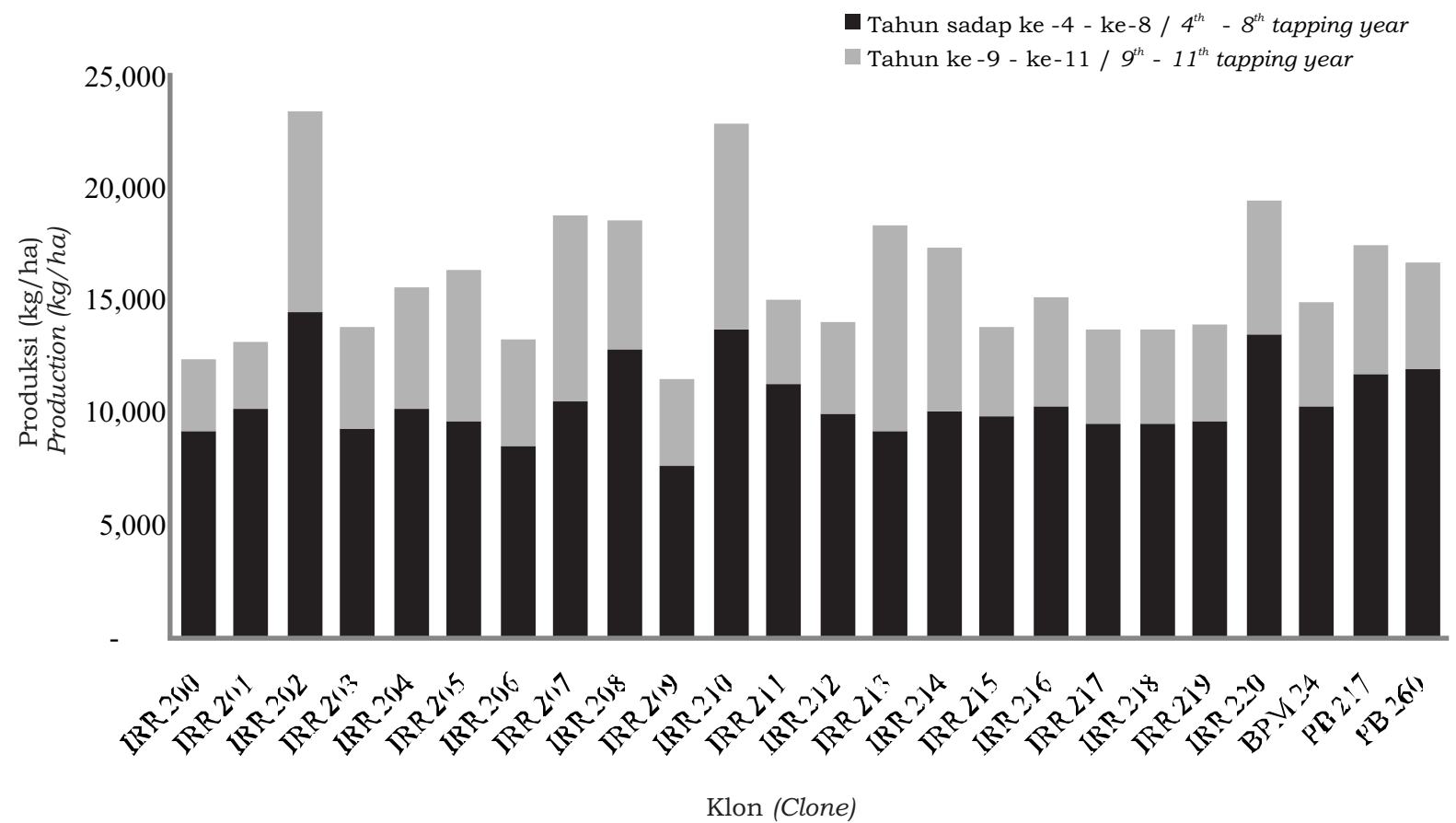

Gambar1. Produksi kumulatif pada perlakuan 1

Figure 1. Cumulative yield in treatment 1 
Tabel 5. Potensi produksi klon pada perlakuan 2

Table 5. Yield potency clone in treatment 2

\begin{tabular}{|c|c|c|c|c|c|c|c|c|c|c|c|}
\hline \multirow{3}{*}{ No. } & \multirow{3}{*}{$\begin{array}{l}\text { Klon } \\
\text { Clones }\end{array}$} & \multicolumn{8}{|c|}{$\begin{array}{l}\text { Tahun sadap ke-n } \\
n \text { tapping year }\end{array}$} & \multirow{3}{*}{$\begin{array}{r}\text { Rataan } \\
(\mathrm{g} / \mathrm{p} / \mathrm{s}) \\
\text { Average } \\
(\mathrm{g} / \mathrm{t} / \mathrm{t})\end{array}$} & \multirow{3}{*}{$\begin{array}{l}\text { Rataan } \\
\text { (kg/ha/th) } \\
\text { Average } \\
(\mathrm{kg} / \mathrm{ha} / \mathrm{yr})\end{array}$} \\
\hline & & \multirow[t]{2}{*}{4} & 5 & 6 & 7 & 8 & 9 & 10 & 11 & & \\
\hline & & & \multicolumn{7}{|c|}{$(\mathrm{g} / \mathrm{p} / \mathrm{s} / \mathrm{g} / \mathrm{t} / \mathrm{t})$} & & \\
\hline \multicolumn{12}{|c|}{ Klon IRR seri 200} \\
\hline \multicolumn{12}{|c|}{ IRR 200 series } \\
\hline 1 & IRR 200 & 33.8 & 38.1 & 49.0 & 54.7 & 67.5 & 30.2 & 19.8 & 23.3 & 39.5 & $1,738.0$ \\
\hline 2 & IRR 201 & 38.9 & 39.2 & 51.2 & 49.3 & 56.8 & 29.4 & 21.6 & 16.9 & 37.9 & $1,667.6$ \\
\hline 3 & IRR 202 & 53.5 & 57.3 & 90.7 & 82.7 & 131.7 & 53.4 & 88.4 & 62.9 & 77.6 & $3,414.4$ \\
\hline 4 & IRR 203 & 29.3 & 27.9 & 47.6 & 67.5 & 67.1 & 49.5 & 27.5 & 27.6 & 43.0 & $1,892.0$ \\
\hline 5 & IRR 204 & 40.2 & 34.8 & 50.3 & 71.2 & 93.2 & 43.6 & 49.3 & 31.7 & 51.8 & $2,279.2$ \\
\hline 6 & IRR 205 & 37.7 & 29.8 & 59.1 & 60.0 & 66.7 & 75.1 & 45.8 & 32.2 & 50.8 & $2,235.2$ \\
\hline 7 & IRR 206 & 34.9 & 33.7 & 55.5 & 50.2 & 59.7 & 43.7 & 35.5 & 29.7 & 42.9 & $1,887.6$ \\
\hline 8 & IRR 207 & 38.8 & 46.9 & 61.9 & 78.9 & 84.8 & 83.1 & 68.8 & 34.5 & 62.2 & $2,736.8$ \\
\hline 9 & IRR 208 & 43.0 & 47.3 & 55.6 & 64.9 & 83.8 & 49.6 & 54.1 & 27.9 & 53.3 & $2,345.2$ \\
\hline 10 & IRR 209 & 30.6 & 29.9 & 42.5 & 49.8 & 56.5 & 36.1 & 26.6 & 26.0 & 37.2 & $1,636.8$ \\
\hline 11 & IRR 210 & 38.8 & 58.7 & 62.9 & 74.9 & 94.9 & 56.2 & 98.1 & 56.5 & 67.6 & $2,974.4$ \\
\hline 12 & IRR 211 & 43.9 & 38.6 & 59.0 & 61.9 & 84.2 & 35.3 & 26.6 & 25.0 & 46.8 & $2,059.2$ \\
\hline 13 & IRR 212 & 36.0 & 44.8 & 46.8 & 54.8 & 63.9 & 40.4 & 27.5 & 24.2 & 42.3 & $1,861.2$ \\
\hline 14 & IRR 213 & 36.5 & 36.7 & 56.2 & 70.6 & 76.4 & 107.3 & 63.2 & 38.9 & 60.7 & $2,670.8$ \\
\hline 15 & IRR 214 & 41.3 & 37.9 & 54.1 & 87.3 & 102.2 & 76.3 & 62.4 & 28.0 & 61.2 & $2,692.8$ \\
\hline 16 & IRR 215 & 34.9 & 39.0 & 51.5 & 65.6 & 78.6 & 36.1 & 36.5 & 20.3 & 45.3 & $1,993.2$ \\
\hline 17 & IRR 216 & 30.5 & 29.0 & 53.2 & 59.7 & 64.5 & 40.7 & 43.9 & 26.4 & 43.5 & $1,914.0$ \\
\hline 18 & IRR 217 & 39.0 & 34.1 & 52.3 & 60.8 & 73.1 & 45.5 & 29.2 & 21.4 & 44.4 & $1,953.6$ \\
\hline 19 & IRR 218 & 30.8 & 24.2 & 38.5 & 47.9 & 53.8 & 42.7 & 26.7 & 26.5 & 36.4 & $1,601.6$ \\
\hline 20 & IRR 219 & 33.9 & 37.8 & 51.5 & 55.7 & 59.2 & 29.7 & 43.6 & 25.6 & 42.1 & $1,852.4$ \\
\hline 21 & IRR 220 & 44.1 & 42.7 & 55.5 & 64.4 & 104.1 & 63.9 & 42.4 & 31.0 & 56.0 & $2,464.0$ \\
\hline $\begin{array}{l}\text { Klon } \\
\text { Cont }\end{array}$ & $\begin{array}{l}\text { mbanding } \\
\text { clones }\end{array}$ & & \multicolumn{8}{|c|}{ Klon pembanding } & \\
\hline 22 & ВPM 24 & 42.0 & 35.6 & 60.7 & 47.5 & 58.8 & 33.0 & 33.6 & 37.3 & 43.6 & $1,918.4$ \\
\hline 23 & PB 217 & 34.4 & 44.5 & 52.6 & 89.3 & 104.5 & 51.5 & 44.3 & 33.2 & 56.8 & $2,499.2$ \\
\hline 24 & PB 260 & 36.4 & 36.5 & 53.1 & 67.6 & 86.3 & 47.2 & 33.8 & 25.8 & 48.3 & $2,125.2$ \\
\hline
\end{tabular}

-- Rataan produksi per tahun dihitung dengan asumsi populasi 400 pohon/ha dan hari sadap efektif 110 hari/tahun Yearly mean yield calculated by assuming a population of 400 trees/ha and effective tapping day 110 days / year

memiliki beberapa sifat spesifik antara lain kurang respons terhadap stimulansia, rentan terhadap kering alur sadap (KAS), dan kulit pulihannya kurang potensial. Adapun klon-klon slow starter secara umum memiliki sifat sebaliknya yaitu respon terhadap stimulansia baik, relatif tahan terhadap tekanan eksploitasi dan kulit pulihannya umumnya sangat potensial.
Dari delapan klon tersebut terdapat lima klon yang dinilai responsif terhadap interval sadap yang tinggi yaitu IRR 202, IRR 207, IRR 208, IRR 210 dan IRR 220. Hal tersebut berdasarkan pengamatan pada perlakuan sistem sadap S/2 d2 kelima klon tersebut memiliki potensi produksi yang lebih tinggi dibanding rata-rata potensi produksi klon-klon IRR seri 200 dan diduga 


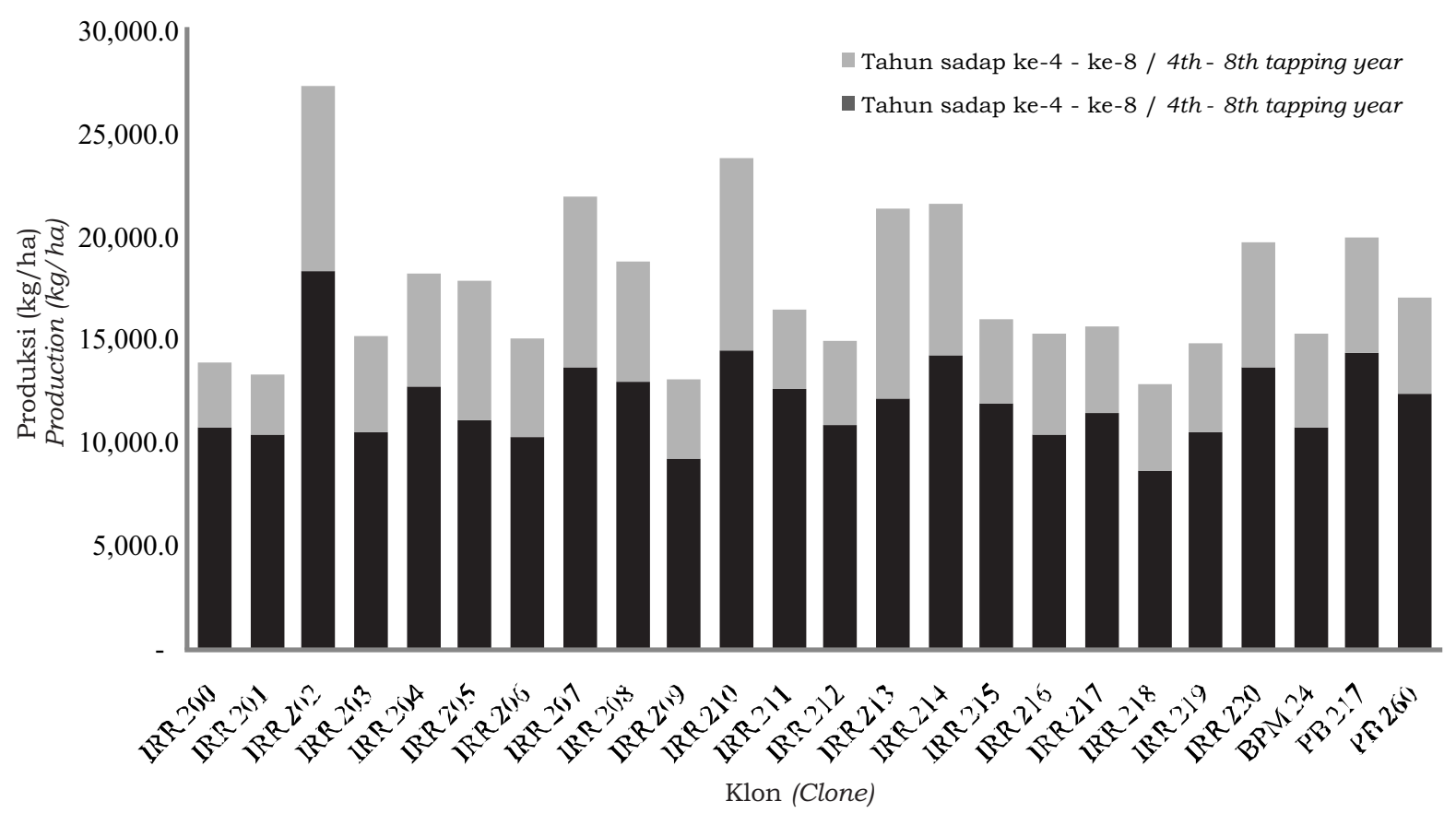

Gambar 2. Produksi kumulatif pada perlakuan 2

Figure 2. Cumulative yield in treatment 2

Tabel 6. Pendugaan tipologi klon berdasarkan respon terhadap sistem sadap

Table 6. Estimation of clonal typology based on the response to tapping system

\begin{tabular}{|c|c|c|c|c|c|c|c|c|}
\hline \multirow{3}{*}{$\begin{array}{c}\text { Uraian } \\
\text { Descriptions }\end{array}$} & \multicolumn{5}{|c|}{$\begin{array}{l}\text { Pengelompokan klon } \\
\text { Clone grouping }\end{array}$} & & & \\
\hline & IRR & IRR & IRR & IRR & IRR & IRR & IRR & IRR \\
\hline & 207 & 202 & 208 & 210 & 220 & 205 & 213 & 214 \\
\hline $\begin{array}{l}\text { Metabolisme lateks } \\
\text { Latex metabolism }\end{array}$ & \multicolumn{5}{|c|}{$\begin{array}{l}\text { Tinggi } \\
\text { High }\end{array}$} & $\begin{array}{l}\text { Sedang } \\
\text { Medium }\end{array}$ & \multicolumn{2}{|c|}{$\begin{array}{l}\text { Rendah } \\
\text { Low }\end{array}$} \\
\hline $\begin{array}{l}\text { Tipologi klon } \\
\text { Clone tipology }\end{array}$ & \multicolumn{5}{|c|}{ Quick starter } & \multicolumn{3}{|c|}{ Slow starter } \\
\hline
\end{tabular}

klon-klon tersebut memiliki metabolisme lateks sedang - tinggi sehingga cukup responsif terhadap interval sadap tinggi (d2). Sebaliknya tiga klon lainnya (IRR 205, IRR 213 dan IRR 214) kurang responsif terhadap interval penyadapan tinggi.

Pengamatan lebih lanjut menunjukkan bahwa dengan pemberian stimulan etephon $2,5 \%$ dan penurunan interval sadap menjadi d3, dari delapan klon yang potensial sebagai klon unggul baru, tersebut terdapat lima yang menunjukkan peningkatan potensi produksi di atas rata-rata klon-klon pembanding yaitu: IRR 202 (26,3\%), IRR 205 (15,3\%), IRR 207 (29,8\%), IRR $213(32,4 \%)$ dan IRR 214 (41,8\%). Klon-klon tersebut diduga memiliki tingkat metabolisme lateks rendah - sedang sehingga responsif terhadap pemberian stimulansia, sedangkan tiga klon lainnya menunjukkan peningkatan yang tidak signifikan masingmasing IRR 208 (1,2\%), IRR 210 (6,2\%) dan IRR $220(1,7 \%)$.

Penggunaan sistem sadap DC bertujuan untuk mengetahui respons tanaman terhadap faktor panjang irisan dan potensi kulit pulihan masing-masing klon IRR seri 200. Pada penambahan irisan (penyadapan ganda/double cut) secara umum respons tanaman mengalami penurunan termasuk pada klon pembanding. Meskipun demikian terdapat tiga klon (IRR 205, IRR 210 dan IRR 
213) yang memiliki respons positif sedangkan lima klon lainnya (IRR 202, IRR 207, IRR 208, IRR 214 dan IRR 220) cenderung mengalami penurunan.

Pendugaan karakteristik tipologi klonal setiap klon dapat dilakukan dengan mengamati respons tanaman terhadap beberapa sistem sadap yang diterapkan dan mengamati karakteristik metabolisme lateks berdasarkan hasil analisis diagnosis lateks. . Klon IRR 202, IRR 208, IRR 210 dan IRR 220 diduga memiliki metabolisme lateks yang tinggi dan tergolong dalam klon quick starter. Kecenderungan produktivitas yang tinggi diperoleh pada penyadapan dengan interval tinggi namun kurang responsif terhadap pemberian stimulan dan penambahan panjang irisan. Aplikasi stimulan dengan konsentrasi 2,5\% hanya meningkatkan produksi kurang dari 5\%. Selain itu, kulit pulihan kurang potensial sehingga pada irisan ganda (DC) produktivitas tanaman tidak meningkat. Secara spesifik klon quick starter lebih responsif terhadap irisan pendek ke arah atas dengan intensitas pemberian stimulan yang relatif rendah (Junaidi et al., 2010).

Klon IRR 205 dan IRR 207 diduga memiliki metabolisme sedang, sedangkan klon IRR 213 dan IRR 214 memiliki metabolisme rendah dan dikelompokkan ke dalam klon slow starter. Klon-klon tersebut memiliki respons cukup baik terhadap pemberian stimulan pada interval sadap yang rendah serta responsif terhadap penambahan irisan sadap. Oleh sebab itu, upaya optimalisasi produksi pada klon-klon tersebut dapat dilakukan dengan pendekatan aplikasi stimulan dan penambahan panjang irisan.

Penilaian terhadap potensi produksi masing-masing klon masih memungkinkan untuk berubah mengingat umur tanaman baru setengah dari umur ekonomisnya. Oleh sebab itu, pengamatan perlu dilanjutkan sampai satu siklus tanaman (sekitar 20 tahun sadap) guna mendapatkan data yang representatif. Selain itu pendugaan karakter klon harus dilengkapai dengan pengamatan karakteristik tanaman berdasarkan analisis diagnosis lateks.

\section{KESIMPULAN DAN SARAN}

Dari hasil pengamatan terhadap karakter pertumbuhan dan potensi produksi masing-masing klon IRR seri 200 pada periode $4-11$ tahun sadap di lokasi pengujian plot promosi ini dapat ditarik beberapa kesimpulan antara lain:

1. Dari sisi pertumbuhan, klon IRR 200, IRR 202, IRR 207, IRR 209, IRR 210, IRR 215, IRR 218, dan IRR 219 berpotensi sebagai klon unggul baru karena memiliki laju pertumbuhan lilit batang lebih tinggi dibanding klon pembanding. Klon - klon tersebut diharapkan dapat mencapai kriteria matang sadap yang lebih singkat (sekitar 3,5 tahun).

2. Dari 21 klon IRR seri 200 yang diujicobakan, terdapat delapan klon yang memiliki potensi produksi lebih tinggi dibanding rata-rata klon pembanding yaitu IRR 202, IRR 205, IRR 207, IRR 208, IRR 210, IRR 213, IRR 214, dan IRR 220. Klon-klon tersebut sangat potensial sebagai klon unggul baru.

3. Klon IRR 202, IRR 208, IRR 210 dan IRR 220 diduga memiliki metabolisme lateks yang tinggi dan tergolong dalam klon quick starter. Kecenderungan produktivitas yang tinggi diperoleh pada penyadapan dengan interval tinggi namun kurang responsif terhadap pemberian stimulan dan penambahan panjang irisan.

4. Klon IRR 205 dan IRR 207 diduga memiliki metabolisme sedang, sedangkan klon IRR 213 dan IRR 214 memiliki metabolisme rendah dan dikelompokkan ke dalam klon slow starter. Klon-klon tersebut memiliki respon cukup baik terhadap pemberian stimulan pada interval sadap yang rendah serta responsif terhadap penambahan irisan sadap.

5. Pengamatan perlu dilanjutkan sampai satu siklus tanaman (sekitar 20 tahun sadap) guna mendapatkan data yang lengkap. Selain itu pendugaan karakter klon harus dilengkapi dengan pengamatan karakteristik tanaman berdasarkan analisis diagnosis lateks. 


\section{DAFTAR PUSTAKA}

Aidi-Daslin, S. Woelan, M. Lasminingsih, H. Hadi, S. Indraty, and I. Suhendry. 2004. New timber-latex clones for rubber planting recommendation. Proc. Int. Rubb. Conf. And Product Exhibition, 2004, 150-158.

Azwar, R dan I. Suhendry. 1998. Kemajuan pemuliaan karet dan dampaknya terhadap peningkatan produktivitas. Pros. Lok. Nas. Pemuliaan 1998 \& Diskusi Nas. Prospek Karet Alam Abad 21, 51-64.

Azwar, R., S. Woelan, dan I. Suhendry. 1999. Pengujian potensi promosi ortet terbaik sebagai klon anjuran baru. Lap. Penelitian 1998/1999. Puslit Karet, 18 p.

Ginting, S. 1984. Hasil pengujian tahap I klon tipe cemara. Kultura. Fakultas Pertanian USU. p. 32.

Junaidi, Sumarmadji, dan Atminingsih. 2010. Pengujian sistem eksploitasi Expex-315 pada klon PB 260. J. Penel. Karet, 2010, 28(2), 41-56.

Simmods, N. W. 1989. Rubber Breeding. In Webster C.C. and Baulkwill, WJ (eds). Rubber. Longman Group, London, 85-124.

Siregar, T. H. S., Junaidi, dan Sumarmadji. 2008. Perkembangan penerapan rekomendasi sistem eksploitasi tanaman karet di perusahaan besar negara. Pros. Lok. Nas. Agribisnis Karet 2008, 217-232.
Sumarmadji. 2000. Sistem eksploitasi tanaman karet yang spesifikdiskriminatif. Warta Pusat Penelitian Karet, 19 (1-3), $31-39$.

Tan, H. 1987. Strategies in Rubber Tree Breeding, In: Cambel, A. I., Abbott, A.J., Attein, R.K. (eds). Improvement of Vegetatively Propagated Plants. Academic Press. London.

Templeton, J. K. 1969a. Partition of assimilates, J. Rubb. Res. Inst. Malaysia 21, 259-63.

Templeton, J. K. 1969b. Where lies the yield summit for Hevea. Plrs'Bull. Rubb. Res. Inst. Malaysia, 104, 220.

Woelan, S., R. Azwar, dan I. Suhendry. 1998. Perakitan dan seleksi genotipe unggul baru. Pros. Lok. Nas. Pemuliaan Karet 1998 \& Diskusi Nas. Prospek Karet Alam Abad 21. 